$\sqrt{3}$

J. Bio-Sci. 23: 67-75, 2015

ISSN 1023-8654

http://www.banglajol.info/index.php/JBS/index

\title{
MICROBIAL, PHYSICOCHEMICAL AND SENSORY CHARACTERISTICS ANALYSIS OF SELECTED ALCOHOLIC BEVERAGES OF FROM BANGLADESH, INDIA AND NEPAL
}

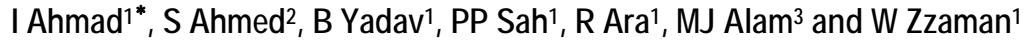 \\ ${ }^{1}$ Department of Food Engineering and Tea Technology, Shahjalal University of Science and Technology \\ Sylhet-3114, Bangladesh; ${ }^{2}$ Department of Microbiology and Hygiene, Sylhet Agricultural University, Sylhet- \\ 3100, Bangladesh; ${ }^{3}$ Department of Genetic Engineering and Biotechnology, Shahjalal University of Science \\ and Technology, Sylhet-3114, Bangladesh
}

\begin{abstract}
Alcoholic beverage is a drink containing ethanol, commonly known as alcohol. Beer is the most widely used alcoholic beverage in the world. To analyze the microbial, physicochemical and sensory characteristics of selected alcoholic beverages, several selected alcoholic beverages (power, strong, crown, hunter, power horse, god father, thunder, bag piper, commando and star gold) of Bangladesh, India and Nepal were used in this study for their analysis. Microbial analysis, physiochemical analysis, and sensory analysis were performed by using standard methods. The results of microbial analysis showed that the standard plate counts of alcoholic beverages were less than 300 colonies. The fungi were present in Nepal and Bangladesh sample but not in Indian samples. In all samples, the presence of coliform was about $0.03 / \mathrm{ml}$ to $2.4 / \mathrm{ml}$. In nutrient agar, creamy smooth colony was found in most of the Nepal and Bangladesh beverages but not in Indian beverages. Hunter contained the highest $\mathrm{pH}$ (4.6) whereas power and bag piper showed the lowest pH values (3.3), strong contained maximum total solid (19.2\%) but bag piper had only $2 \%$ total solid, big piper contained the highest amount of alcohol (18.25\%) although power contained only 3.15\% alcohol. Sensory evaluation of all the samples was quite acceptable as an alcoholic beverage. Among the alcoholic beverages it might be concluded that Nepal beverages are the best product in respect of sensory evaluation, but considering microbial analysis Indian beverages are the best.
\end{abstract}

Key words: Alcoholic beverage, microbial quality, physicochemical analysis, sensory test

\section{Introduction}

Beer is perhaps the most widely used alcoholic beverage. It is the third largest drink consumed all over the world after water and tea. Moderate use of beer in the daily diet can be good but drinking beer exceeds a certain limit would be harmful (Gaetano et al. 2016). Wine is another common alcoholic beverage and everybody is familiar with it. The spirits are also used in making alcohol beverages. The liqueur is the best example of a spirit which is used widely. Beer and wine are the things which are widely used and have the most popularity. Among the beer lager and all are quite popular. There are still many more varieties of alcohols (Roger 2001). Wine is a principally fermented juice. It may also be produced by fermentation of juice of fruit such as apple, peaches, apricots, plums, pears, cherries and berries. Wine is red or white depending on the skin of purple (Lourenço 2012). Fruit wines have traditionally been popular with home winemakers and in areas with cool climates such as North America and Scandinavia. Most fruits and berries have the potential to produce wine. However, the amount of fermentable sugars is often low and

*Author for correspondence: iftekharfet.sust@yahoo.com 
need to be supplemented by a process called capitalization in order to have sufficient alcohol levels. Sucrose is often added so that fruits having excessive levels of acids (usually citric or malic acid) can split the sucrose into fermentable fructose and glucose sugars (Chiva-Blanch et al. 2015). Many fruit wines suffer from a lack of natural yeast nutrients needed to promote or maintain fermentation. Winemakers can counter this with the addition of nitrogen, phosphorus and potassium (Yasui et al. 1991). Unlike some grape-based wines, fruit wines often do not improve with bottle age and are usually meant to be consumed within a year of bottling. Fortified wines are made in the Republic of South Africa and North Africa (Dawson et al. 2005).

Fortified wines are made by adding spirits to wines, either during or after fermentation, with the result that the alcohol content of the wines is raised to around $20 \%$, i.e. approximately double that of the table wines. Jackfruit (Artocarpus heterophyllus) wine is an alcoholic beverage made by ethnic groups in the eastern hilly areas of India. As its name suggests, it is produced from the pulp of jack-fruit, ripe fruit is peeled and the skin was discarded (Dawson 2008a). During fermentation, the $\mathrm{pH}$ of the wine reaches a value of 3.5 to 3.8 , suggesting that an acidic fermentation takes place at the same time as the alcoholic fermentation (Poli et al. 2013). Final alcohol content is about 7 to $8 \%$ within a fortnight. The term wine can sometimes include alcoholic beverages that are not grape-based. This can include wines produced from fruits like apples and elderberries, starches like rice, as well as flowers and weeds like dandelion and marijuana (Poli et al. 2013). The most common, narrow definition of wine relates to the product of fermented grape juice, though it is sometimes broadened to include any beverage with a fermentation based on the conversion of a sugar solution into alcohol (fermented beverages based on hydrolyzed barley such as beer are often excluded). Some drinks such as cider, mead and perry are also excluded from this broad definition of wine for historical reasons (Castellar et al. 2003). There were no scientific studies found regarding microbial, physicochemical and sensory analysis of those beverages. Therefore the present study was carried out to evaluate the microbial, physicochemical and sensory analysis of mentioned alcoholic beverages.

\section{Materials and Methods}

This study was conducted during the period of February - June 2011, Department of Food Engineering and Tea Technology, Shahjalal University of Science and Technology, Sylhet and Department of Microbiology and Hygiene, Sylhet Agricultural University, Sylhet.

\section{Microbial analysis of alcoholic beverages}

Microbial analysis were carried out by the pour plate/spread plate method using plate count agar, sabouraud dextrose agar and nutrient agar, lactose broth for total aerobic bacteria and total yeast count respectively. Colony counts were done after the appropriate period of incubation.

The standard plate count was done by the pour-plate/ spread plate technique (Breed and Dotterer 1916). Colony counts were considered for 30-300 colonies/plate and others were discarded. In total fungal count technique, the sample was approximately diluted $(0.5 \mathrm{ml})$ and transferred to a SDA plate. Then the sample was distributed evenly over the surface by a spreader. After colonies were grown, those were counted and the numbers of microbes in the original sample were calculated. The most probable number technique, counting the number of tubes showing a positive result and comparing with standard chart, a statistical estimation of the most probable number (MPN) of bacteria were made. This was an estimate of lactose fermenting bacteria. 


\section{Physicochemical characteristics of alcoholic beverages}

\section{Determination of $\mathrm{pH}$ of alcoholic beverages}

$10 \mathrm{ml}$ of the alcoholic beverage was shaken with $100 \mathrm{ml}$ of water and allowed to stand for a period of $30 \mathrm{~min}$. Then the material was filtered and the $\mathrm{pH}$ of the filtrate was determined with a $\mathrm{pH}$ meter.

\section{Determination of acidity in alcoholic beverages}

Water extracts method (AOAC 1990) was used in the determination of acidity. Eighteen milliliter of alcoholic beverage was measured and shaken with $200 \mathrm{ml}$ of $\mathrm{CO}_{2}$ free water in a conical flask and placed in a water bath at $40^{\circ} \mathrm{C}$ for $1 \mathrm{~h}$ with the flask loosely stopped. It was filtered and $100 \mathrm{ml}$ of the clear filtrate was titrated with $0.05 \mathrm{M}$ of $\mathrm{NaOH}$ solution with phenolphthalein indicator. The acidity of water extract increases during storage and is calculated as lactic acid or potassium dihydrogen phosphate $(1 \mathrm{ml}$ of $0.05 \mathrm{M}$ of $\mathrm{NaOH}=$ $0.0068 \mathrm{~g}$ of $\mathrm{KH}_{2} \mathrm{PO}_{4}$ ).

\section{Determination of total solid inalcoholic beverages}

$5 \mathrm{~g}$ of alcoholic beverage was weighed into a flat-bottomed metal dish (or small beaker) and placed on boiling water for about $30 \mathrm{~min}$. until the liquid evaporated leaving the solid. It was then transferred into an oven maintained at $100^{\circ} \mathrm{C}$ for $2^{1 / 2} \mathrm{~h}$ as $\mathrm{W}_{2}$. It was then transferred to desiccators, cooled and weighed. It was heated in the oven again for $1 \mathrm{~h}$, cooled and weighed. The process was continued until constant weight $\mathrm{W}_{3}$, was obtained (AOAC 1990). The total solid was calculated from the following equation:

Total solid $=W_{3}-W_{1} / W_{2}-W_{1} \times 100$

\section{Determination of protein in alcoholic beverages}

The mole titration method (Pirie 1975, Lourenço et al. 2012) was used for the determination of protein contents in alcoholic beverages. $10 \mathrm{ml}$ of alcoholic beverage was added to $0.05 \mathrm{ml}$ of $0.5 \%$ phenolphthalein indicator. It was mixed and allowed to stand for a few minutes and neutralized with $0.1 \mathrm{M} \mathrm{NaOH}$ to the standard pink color. $2 \mathrm{ml}$ of formalin was added, mixed and allowed to stand for few minutes. The new acidity produced was titrated with $0.1 \mathrm{M} \mathrm{NaOH}$ to the same pink color. Then $2 \mathrm{ml}$ of the formalin $+10 \mathrm{ml}$ of $\mathrm{H}_{2} \mathrm{O}$ were titrated separately with $0.1 \mathrm{M} \mathrm{NaOH}$ as blank.

\section{Determination of ash in alcoholic beverages}

The crucible dish was cleaned, dried ignited, cooled and weighed as $W_{1} .24 .4 \mathrm{~g}$ of the alcoholic beverage was weighed accurately and directly in the dish i.e. $W_{2}$. The substance was dried on a boiling water bath and the charred over a bursen flame or hot plate in fume cupboard until no more soot was given out. It was then ashed with a muffle furnace at $500^{\circ} \mathrm{C}$ to obtain $W_{3}$ (AOAC 1990). Percentage of ash was calculated from the following equation:

Ash (\%) $=W_{3}-W_{1} / W_{2}-W_{1} \times 100$ 


\section{Determination of moisture content in alcoholic beverages}

This method is based on loss on dry at an oven temperature at $105^{\circ} \mathrm{C}$. Besides water the loss will include other matter volatile at $105^{\circ} \mathrm{C}$ (AOAC 1990). $5 \mathrm{~g}$ of alcoholic beverage was weighed into a pre-weighted flat dish $\left(\mathrm{W}_{1}\right)$ and dried at an oven temperature of $105^{\circ} \mathrm{C}$ for $3 \mathrm{~h}$ as $\mathrm{W}_{2}$. It was allowed to cool in airtight desiccators and reweighed. It was heated in the oven again for half an hour, cooled and weighed. The process was repeated until constant weight was obtained $W_{3}$ (AOAC 1990). The percentage moisture was calculated from the following equation:

Moisture (\%) $=W_{2}-W_{3} / W_{2}-W_{1} \times 100$.

\section{Determination of alcohol contents in alcoholic beverages}

Alcohol contents of the sample beverages were determined using ABV method as described elsewhere (Tapson 2004).

\section{Sensory evaluation of alcoholic beverages}

Sensory attributes (such as colour/appearance, flavour, texture, and overall acceptability) were evaluated using a 9 point hedonic scale (where $9=$ like extremely, $8=$ like very much, $7=$ like moderately, $6=$ like slightly, 5 = neither like nor dislike, 4 = dislike slightly, 3 = dislike moderately, 2 = dislike very much, $1=$ dislike extremely) by 16 panelists (gender: 8 men: 8 women; age group: 20 - 40) selected from teachers, students and staff of several departments. Samples were served in clean transparent glasses. Questionnaires and water for mouth rinsing between each tasting were provided. Prior to evaluation, a session was held to familiarize panelists with the products. Panelists were asked to read through the questionnaires and the meaning of each attribute (colour/appearance, flavour, texture, and overall acceptability) was explained to the panelists to avoid any misinterpretation. Tasters were not allowed to discuss their scores with one another during the evaluation session. We have taken one sample of each country for sensory evaluation, from India (thunder), Nepal (commando) and Bangladesh (hunter).

\section{Results and Discussion}

\section{Microbial analysis of alcoholic beverages}

The microbial analysis for different parameters like the standard plate count (SPC), fungal count (FU), most probable number (MPN) count, Escherichia coli (E. coli) count of the alcoholic beverages were shown in Table 1, 2 and 3. The SPC of alcoholic beverages was more than 30 colonies but less than 300 colonies. When the colony forming unit is more than 30 colonies and less than 300 colonies then the SPC was suitable for plate counting. The fungi were present in Nepal and Bangladesh samples but not in Indian samples. In all the samples, the presence of $E$. coli form was about $0.03 / \mathrm{ml}$ to $4.6 / \mathrm{ml}$ (Tables 1-3). In nutrient agar (NA), creamy smooth colony was found in most of the alcoholic beverages which were collected from Nepal and Bangladesh but out of three Indian samples, two did not form any colony. 
Table 1. Microbial analysis of alcoholic beverages of Bangladesh.

\begin{tabular}{lcccc}
\hline Sample name & $\begin{array}{c}\text { SPC } \\
\text { CFU/ml }\end{array}$ & $\begin{array}{c}\text { FC } \\
\text { CFU/ml }\end{array}$ & $\begin{array}{c}\text { E. coli count } \\
\text { MPN/ml }\end{array}$ & Colony in NA \\
\hline Power & $7 \times 10^{6}$ & Fungus present & 0.13 & Creamy smooth colony \\
Strong & $>30$ colony & Fungus absent & 0.03 & Do \\
Crown & $74 \times 10^{4}$ & Fungus present & 2.10 & Do \\
Hunter & $98 \times 10^{3}$ & Fungus present & 0.44 & Do \\
Power horse & $43 \times 10^{4}$ & Fungus absent & 0.09 & Do \\
\hline
\end{tabular}

Table 2. Microbial analysis of alcoholic beverages of India.

\begin{tabular}{lcccc}
\hline Sample name & SPC & FC & E. coli count & Colony in NA \\
& CFU/ml & CFU/ml & MPN/ml & \\
\hline God father & $>30$ colony & Fungus absent & 0.03 & No colony found \\
Thunder & $52 \times 10^{6}$ & Fungus present & 2.4 & Creamy smooth colony \\
Bag piper & $>30$ colony & Fungus absent & 0.03 & No colony found \\
\hline
\end{tabular}

Table 3. Microbial analysis of alcoholic beverages of Nepal.

\begin{tabular}{lcccc}
\hline Sample name & SPC & FC & E. coli count & Colony in NA \\
& CFU/ml & CFU/ml & MPN/ml & \\
\hline Commando & $6 \times 10^{7}$ & Fungus present & 4.60 & Creamy smooth colony \\
Star gold & $32 \times 10^{6}$ & Do & 0.93 & Do \\
\hline
\end{tabular}

\section{Physicochemical characteristics of alcoholic beverages}

The $\mathrm{pH}$ of the 10 samples was found in the range of 3.3 to 4.6 (Tables 4-6). The $\mathrm{pH}$ of the samples were 3.3, 4.3, 4.4, 4.6, 4.5, 4.2, 4.5, 3.3, 4.5, 3.8 for power, strong, crown, hunter, power horse, god father, thunder, bag piper, commando and star gold, respectively; where hunter showed the highest pH (4.6) but power had the lowest pH (3.3). All the samples collected from Bangladesh, India, and Nepal had almost similar pH values (Tables 4-6). Ortiz-Laurel et al. (2000) observed that pH of the alcoholic beverages before and after storage around similar and within the range of 3.8 to 4.3 .

The total solid of alcoholic beverages were found 17.6, 19.2, 2.6, 3.0, 12.4, 3.8, 3.8, 2.0, 3.6 and 3.0\% for power, strong, crown, hunter, power horse, god father, thunder, bag piper, commando and star gold, respectively (Tables 4-6). The highest solid content in Bangladesh sample was $17.6 \%$ in power and the lowest was 2\% (Tables 4-6) in Indian sample bag piper. From Germany beer institute, alcoholic beverages (beer) contain 11 to $14 \%$ of total solid (Rehm et al. 2003). 
The percentage of total protein in alcoholic beverages were observed as $0.23,0.42,0.81,0.91,0.13,3.45$, 2.3, 3.6, 2.75 and $3.06 \%$ for power, strong, crown, hunter, power horse, god father, thunder, bag piper, commando and star gold, respectively (Tables 4, 5 and 6 ). The protein contents of alcoholic beverage made it to be more nutritious than any of the alcoholic beverages (beer), which seems to have contained less protein content (Dawson et al. 2008b).

The acidity of alcoholic beverages were found as $1.26,1.53,1.52,1.63,0.88,3.26,0.97,1.36,1.90$ and $1.18 \%$ for power, strong, crown, hunter, power horse, god father, thunder, bag piper, commando and star gold, respectively (Tables 4-6). The acidity in alcoholic beverages was calculated as potassium dihydrogen phosphate $\left(\mathrm{KH}_{2} \mathrm{PO}_{4}\right)$.

Table 4. Physicochemical characteristics of alcoholic beverages of Bangladesh.

\begin{tabular}{lccccccc}
\hline $\begin{array}{l}\text { Sample } \\
\text { name }\end{array}$ & pH & $\begin{array}{c}\text { Total solid } \\
(\%)\end{array}$ & Protein (\%) & Acidity (\%) & Ash (\%) & $\begin{array}{c}\text { Moisture content } \\
(\%)\end{array}$ & Alcohol (\%) \\
\hline Power & 3.3 & 17.6 & 0.23 & 1.26 & 1.06 & 76.70 & 3.15 \\
Strong & 4.3 & 19.2 & 0.42 & 1.53 & 2.50 & 73.13 & 3.22 \\
Crown & 4.4 & 2.6 & 0.81 & 1.52 & 0.08 & 90.28 & 4.70 \\
Hunter & 4.6 & 3.0 & 0.91 & 1.63 & 0.04 & 89.62 & 4.80 \\
Power horse & 4.5 & 12.4 & 0.13 & 0.88 & 0.73 & 81.32 & 4.54 \\
\hline
\end{tabular}

Table 5. Physicochemical characteristics of alcoholic beverages of India.

\begin{tabular}{lccccccc}
\hline $\begin{array}{l}\text { Sample } \\
\text { name }\end{array}$ & $\mathrm{pH}$ & $\begin{array}{c}\text { Total solid } \\
(\%)\end{array}$ & $\begin{array}{c}\text { Protein } \\
(\%)\end{array}$ & $\begin{array}{c}\text { Acidity } \\
(\%)\end{array}$ & $\begin{array}{c}\text { Ash } \\
(\%)\end{array}$ & $\begin{array}{c}\text { Moisture } \\
\text { content (\%) }\end{array}$ & $\begin{array}{c}\text { Alcohol } \\
(\%)\end{array}$ \\
\hline God father & 4.2 & 3.8 & 3.45 & 3.26 & 0.08 & 82.45 & 6.95 \\
Thunder & 4.5 & 3.8 & 2.30 & 0.97 & 0.12 & 85.69 & 7.12 \\
Bag piper & 3.3 & 2.0 & 3.60 & 1.36 & 0.04 & 74.75 & 18.25 \\
\hline
\end{tabular}

Table 6. Physicochemical characteristics of alcoholic beverages of Nepal.

\begin{tabular}{lccccccc}
\hline Sample name & $\mathrm{pH}$ & $\begin{array}{c}\text { Total solid } \\
(\%)\end{array}$ & $\begin{array}{c}\text { Protein } \\
(\%)\end{array}$ & $\begin{array}{c}\text { Acidity } \\
(\%)\end{array}$ & $\begin{array}{c}\text { Ash } \\
(\%)\end{array}$ & $\begin{array}{c}\text { Moisture } \\
\text { content } \\
(\%)\end{array}$ & $\begin{array}{c}\text { Alcohol } \\
(\%)\end{array}$ \\
\hline Commando & 4.4 & 3.6 & 2.75 & 1.90 & 0.80 & 85.36 & 5.55 \\
Star gold & 3.8 & 3.0 & 3.06 & 1.18 & 0.16 & 86.15 & 6.45 \\
\hline
\end{tabular}

The value of ash contents of the alcoholic beverages were ranges from 0.04 to $2.50 \%$ and were estimated as $1.06,2.50,0.08,0.04,0.73,0.08,0.12,0.04,0.8$ and $0.16 \%$ for power, strong, crown, hunter, power horse, god father, thunder, bag piper, commando and star gold, respectively (Tables 4-6). The lower amount of ash was found samples in Indian compared with Nepal and Bangladesh (IARC 1988).

The moisture contents of the alcoholic beverages were in the range of about 73 to $91 \%$ (Tables 4-6). The moisture contents of the different samples were measured as $76.70,73.13,90.28,89.62,81.32,82.45$, 
$85.69,74.75,85.36$ and $86.15 \%$ for power, strong, crown, hunter, power horse, god father, thunder, bag piper, commando and star gold, respectively (Tables 4, 5 and 6). The moisture contents of the experimental alcoholic beverages were almost similar to that of the values as suggested previously ranging from 80 to $90 \%$.

The alcohol contents of alcoholic beverages were found to be $3.15,3.22,4.70,4.80,4.54,6.95,7.12,18.25$, 5.55 and 6.45 for power, strong, crown, hunter, power horse, god father, thunder, bag piper, commando and star gold, respectively (Tables 4-6). The highest alcohol contents was observed samples in Indian (bag piper 18.25\%, Table 5) while the lowest alcohol was present in Bangladeshi samples (power 3.15\%, Table 4).

\section{Sensory evaluation of alcoholic beverages}

Sensory evaluation of the alcoholic beverages is shown in the Fig 1. Regarding the data, it was observed that samples in Nepal were the best beverages in all aspects e.g. color, flavor, texture, and overall acceptability, whereas samples in Bangladeshi and Indian showed almost similar sensory acceptability

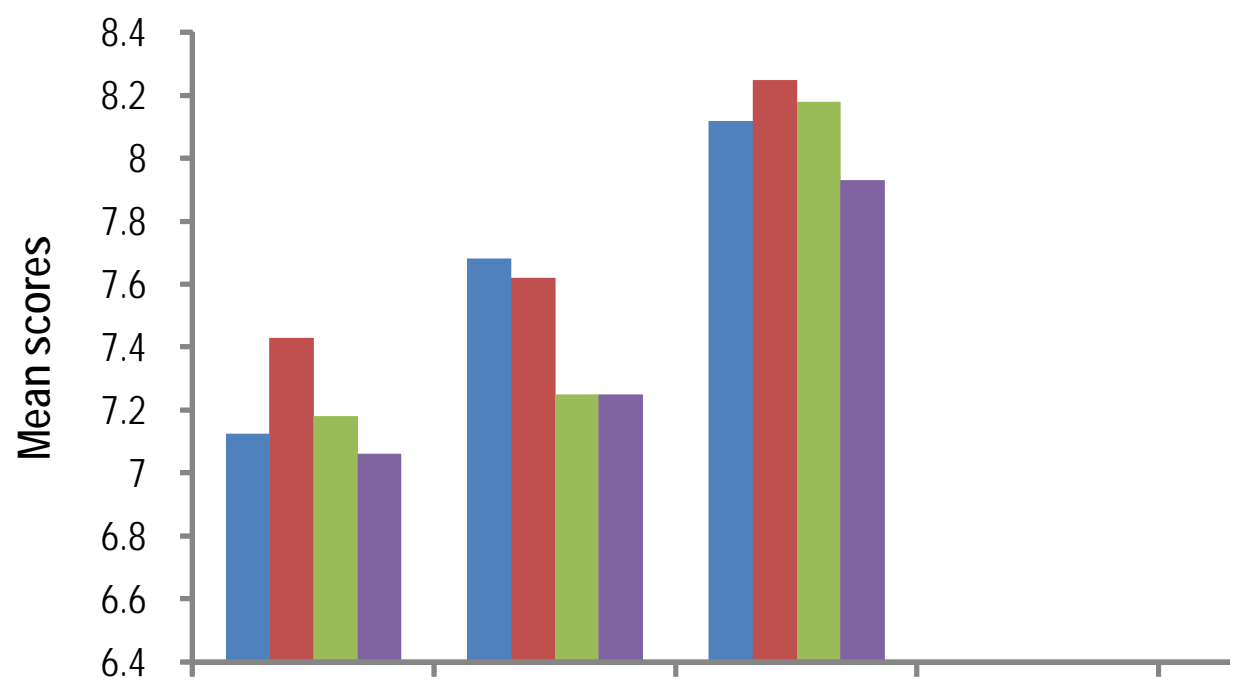

Fig. 1. Frequency score of sensory characteristics of alcoholic beverages.

Chowdhury and Ray (2007) reported that preliminary sensory evaluation analysis of "Jamun wine" is inferior (except colour/appearance) to commercial grape wine $(p<0.05)$ but the attributes like aroma, taste, after taste and colour/appearance were scored at about 3.0 (like much). However, the panelists rated flavour scores between 2.0 - 3.0 (like moderately- like much) probably because of high tannin content in jamun wine which imparted somewhat an astringent flavour. Nevertheless, the jamun wine was acceptable to all the panelists. Adebayo et al. (2010) studied that sensory attributes of "Kunu" samples with respect to taste, odour, colour, texture, flavour and general acceptability. All the samples remain acceptable only within the first 48 hrs of storage at all temperatures and it can be stored in the refrigerator for five days without spoilage. This is also supported by the fact that the $\mathrm{pH}$ has fallen to acidic level within the same period. The colour and taste became unattractive after $48 \mathrm{hrs}$ of storage at room temperature. 


\section{Conclusion}

From the above studies it may be concluded that Indian sample is good in compare to Nepal and Bangladesh samples. Indian samples contain small amount of microorganism and the physicochemical characteristics of Indian samples showed that those contain low amount of total solid, ash and acid; which is good for human health. Among the alcoholic samples, Nepal beverages are the best product in respect to sensory evaluation.

\section{References}

Adebayo GB, Otunola and Ajao TA (2010). Physicochemical, microbiological and sensory characteristics of kunu prepared from millet, maize and guinea corn and stored at selected temperatures, Advanced Journal of Food Science and Technology 2(1): 41-46.

AOAC (1990). Official Methods of Analysis, Association of Analytical Chemistry. 15th Ed. Washington DC: 1-1546 pp.

Breed RS and Dotterer WD (1916) The number of colonies allowable on satisfactory agar plates, New York Agricultural Experimental Station Technology Bulletin, 53-63 pp.

Castellar MR, Obón JM, Alacid M and Fernández-López JA (2003). Color properties and stability of betacyanins from Opuntia fruits, Journal of Agricultural and Food Chemistry 51: 2772-2776.

Chiva-Blanch G, Magraner E, Condines X, Valderas-Martínez P, Roth I and Arranz S (2015). Effects of alcohol and polyphenols from beer on atherosclerotic biomarkers in high cardiovascular risk men: a randomized feeding trial, Nutrition, Metabolism and Cardiovascular Diseases 25: 36-45

Chowdhury P and Ray RC (2007). Fermentation of Jamun (Syzgium cumini L.) fruits to form red wine, ASEAN Journal of Food 14(1): 15-23.

Dawson DA, Grant BF, Stinson FS, Chou PS, Huang B and Ruan WJ (2005). Recovery from DSM-IV alcohol dependence: United States 2001-2002. Addiction 100(3): 281-292.

Dawson DA, Goldstein RB, Chou SP, Ruan WJ and Grant BF (2008a). Age at first drink and the first incidence of adult onset DSM-IV alcohol use disorders Alcoholism, Clinical Experimental Research 32(12): 2149-2160.

Dawson DA, Stinson FS, Chou SP and Grant BF (2008b). Three-year changes in adult risk drinking behavior in relation to the course of alcohol use disorders, Journal of Studies on Alcohol and Drugs 69(6): 866-877.

Gaetano G, Costanzo S, Castelnuovo AD, Badimon L, Bejko D, Alkerwi A, Chiva-Blanch, Estruch R and Vecchia CL (2016). Effects of moderate beer consumption on health and disease: A consensus document, nutrition, Metabolism and Cardiovascular Diseases 26(6): 443-467.

IARC (1988). Alcohol drinking. IARC monographs on the valuation of carcinogenic risk of chemicals to humans, International Agency for Research on Cancer, Lyon, France 44: 416.

Lourenço S, Oliveira A and Lopes C (2012). The effect of current and lifetime alcohol consumption on overall and central obesity, European Journal of Clinical Nutrition 66(7): 813-818.

Ortiz-Laurel H and Mendez-Gallegos SJ (2000). Production of melcocha and queso de tuna from cactus pear fruit in the centre of Mexico, Food Chain 26: 20-21.

Poli A, Marangoni F, Avogaro A, Barba G, Bellentani S, Bucci M, Cambieri R and Catapano AL (2013). Moderate alcohol use and health: A consensus document Nutrition, Metabolism and Cardiovascular Diseases 23(6): 487-504

Pirie NW (1975). Food protein source rothameted experimental station harpenter, UK. 4th Edn. 1-121 pp. 
Rehm J, Room R, Graham K, Monteiro M, Gmel G and Sempos CT (2003). The relationship of average volume of alcohol consumption and patterns of drinking to burden of disease: an overview, Addiction 98: 1209-28.

Roger B, Vernon L, Singleton, Linda F, Bisson and Kunkee RE (2001). The Principles and practices of winemaking. Frederick, MD: Aspen Publishers, pp 1999.

Tapson F (2004). Determination of Alcohol Content in Alcoholic Beverages Using 45 MHz Benchtop NMR Spectrometer, International Journal of Spectroscopy 6: 1-8.

Yasui M, Yase Y, Ota K and Garruto RM (1991). Evaluation of magnesium, calcium and aluminum metabolism in rats and monkeys maintained on calcium-deficient diets, Neurotoxicology 12(3): 603-614. 
